\title{
Approaches to Classroom Assessment Inventory: A New Instrument to Support Teacher Assessment Literacy
}

\author{
Christopher DeLuca ${ }^{a}$, Danielle LaPointe-McEwan ${ }^{a}, \&$ Ulemu Luhangab \\ aFaculty of Education, Queen's University, Kingston, Canada \\ bSchool of Medicine, Emory University, Atlanta, United States
}

Full Citation:

Christopher DeLuca, Danielle LaPointe-McEwan \& Ulemu Luhanga (2016) Approaches to Classroom Assessment Inventory: A New Instrument to Support Teacher Assessment Literacy, Educational Assessment, 21:4, 248-266,

DOI: 10.1080/10627197.2016.1236677

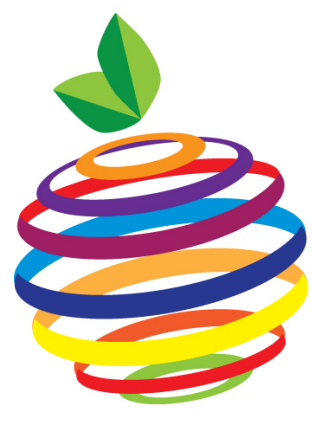

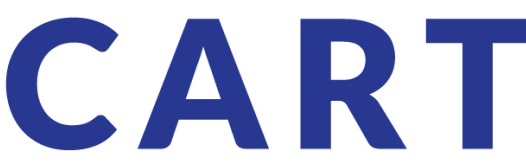

Classroom Assessment Research Team cdeluca.com
Contact:

Christopher DeLuca cdeluca@queensu.ca @ChrisDeLuca20 


\begin{abstract}
Teacher assessment literacy has become a central priority across many educational systems in North America and elsewhere in response to growing accountability demands. While many scholars have aimed to measure teacher assessment literacy, recent research has identified that current assessment literacy instruments do not fully reflect current transformations in the assessment landscape and remain predicated on dated standards for teacher classroom assessment practice. Recently published assessment standards articulate contemporary approaches to classroom assessment. Given these significant shifts in classroom assessment, the purpose of this paper is to construct a reliable instrument reflective of contemporary assessment practices and contexts. Specifically, this paper describes our instrument development process including construct validation and reliability testing with over 400 teachers. The result of this research is the Approaches to Classroom Assessment Inventory, which can be used by researchers and practitioners to support teacher assessment literacy in relation to the current accountability framework evident across educational systems.
\end{abstract}

Keywords: assessment literacy, classroom assessment, assessment competency, professional learning 
Teacher assessment literacy has become a central priority across many educational systems in North America and elsewhere in response to growing accountability demands (DeLuca, LaPointe-McEwan, \& Luhanga, 2015; Gotch \& French, 2014; Popham, 2013). Specifically, assessment literacy has been defined as the skills and knowledge teachers require to measure and support student learning through assessment (Brookhart, 2011; Popham, 2013). Researchers have constructed instruments to measure and track teachers' assessment literacy in an effort to support teachers' classroom assessment practices. However, based on their recent systematic review of 36 literacy measures, Gotch and French (2014) found that there is weak psychometric evidence supporting these measures and that existing instruments lack "representativeness and relevance of content in light of transformations in the assessment landscape (e.g., accountability systems, conceptions of formative assessment)" (p. 17). These findings are not surprising given that the majority of assessment literacy measures are predicated on assessment standards from the early 1990s (i.e., Standards for Teacher Competency in Educational Assessment of Students; AFT, NCME \& NEA, 1990) (DeLuca et al., 2015; Gotch \& French, 2014). Hence, the purpose of this research is to develop a new instrument to understand teachers' approaches to classroom assessment as related to contemporary professional standards in assessment.

While the 1990 assessment standards were useful in supporting teacher learning and describing valuable assessment practices, Brookhart (2011) recognized that the standards no longer fully account for the range of assessment activities or the assessment knowledge teachers require within the current landscape of schooling. In particular, Brookhart noted that the standards need to be revised in recognition of three dominant shifts: (a) the increased reliance on assessments for accountability purposes, including large-scale and standardized measures 
administered within classroom contexts and related to teacher instruction and evaluation; (b) formative assessment activities including contemporary conceptions of assessment for and as learning; and (c) the enactment of assessments within and in response to highly diverse (i.e., socio-cultural, linguistic, ability, etc.) teaching contexts. We further add the emerging trend towards assessment education — a deliberate focus within professional learning communities to enhance and support teachers' assessment practices and data-literacy (DeLuca et al., 2015). Combined, the absence of these core aspects of current assessment practices diminishes construct representation within existing assessment literacy measures and limits the validity of inferences drawn about teachers' knowledge and skills (Brookhart, 2011; DeLuca et al., 2015; Gotch \& French, 2014).

Given the significant shifts in the assessment landscape over the past 20 years, in this paper we aim to construct a reliable instrument reflective of current assessment practices and contexts. Specifically, we draw on the recently developed Classroom Assessment Standards (Joint Committee on Standards for Educational Evaluation, 2015) as a basis for delineating teachers' current assessment practices. Based on our analysis of those and other assessment documents, we present our process for developing a new assessment literacy measure including construct validity testing and initial psychometric evidence drawn from a sample of over 400 teachers. We conclude by discussing the potential uses of this assessment literacy instrument for teachers, professional learning, and future research.

\section{Previous Measures of Teacher Assessment Literacy}

Several researchers have aimed to measure teacher assessment literacy or its proxy construct, assessment competency. The majority of these studies have involved quantitative measures based on the original 1990 Standard for Teacher Competency in Educational 
Assessment of Students (AFT, NCME \& NEA, 1990). In their seminal study, Plake, Impara and Fager (1993) examined the assessment competency of 555 teachers and 268 administrators across 45 states in the US. In the first part of their study, a 35-item instrument, the Teacher Competencies Assessment Questionnaire (TCAQ), was developed to measure the seven competency Standards. Each Standard was measured through five multiple-choice items. The instrument was reviewed by a 10-member panel from the National Council on Measurement in Education (NCME) in order to establish construct validity before being pilot-tested with 70 teachers to establish reliability estimates (Crocker \& Algina, 2006). As the first study to explore teacher assessment competency, results pointed to significant gaps in teachers' understanding and use of assessments as evidenced by an average score of $66 \%$ across the 35 items. Specifically, participants lacked competency in interpreting, integrating, and communicating assessment results. Plake et al. later used their results as a basis for professional development programming.

Building on Plake et al.’s (1993) research, O’Sullivan and Johnson (1993) used the TCAQ with 51 graduate students enrolled in a measurement course for teachers. The course exposed students to performance-based tasks that were linked to the Standards (AFT, NCME \& NEA, 1990). Accordingly, the purposes of their study were to: (a) examine the alignment between TCAQ items and practical assessment tasks, and (b) to determine students' learning in relation to the Standards. In addition to pre- and post-TCAQ administrations, participants were asked to complete the Classroom Assessment Tasks (CAT) survey to gauge alignment between the Standards and the performance assessment tasks. CAT responses supported strong alignment of performance tasks with the Standards leading to further validity evidence for the TCAQ. Similarly, Campbell, Murphy, and Holt (2002) administered a revised version of the TCAQ to 
220 undergraduate students enrolled in a pre-service measurement course. Based on their analysis, Campbell et al. found that teacher candidates' competency differed across the seven Standards. Accordingly, these researchers concluded that teacher candidates lacked critical aspects of competency upon entering the teaching profession. Mertler (2003) identified a similar trend when he administered the TCAQ to 67 pre-service and 197 practicing teachers. Mertler's results paralleled Plake et al.’s (1993) and Campbell et al.'s studies.

In 2004, Mertler and Campbell collaborated on reconceptualizing the TCAQ into the Assessment Literacy Inventory (ALI; Mertler \& Campbell, 2004, 2005). Their aim was to contextualize the items by restructuring them into scenario-based questions, reflecting a more practical orientation to the Standards (AFT, NCME \& NEA, 1990). The ALI included seven scenarios, each linked to one of the Standards, with a series of five multiple-choice questions. Like O’Sullivan and Johnson (1993), Mertler and Campbell (2004, 2005) administered the ALI to teachers enrolled in a measurement course to determine student learning in relation to the Standards. Similar to previous studies, teacher assessment literacy was still relatively low across critical assessment competencies.

Brown (2004) and his later work with colleagues (e.g., Brown, Hui, Yu, \& Kennedy, 2011; Harris \& Brown, 2009; Hirschfeld \& Brown, 2009) used the Teachers’ Conceptions of Assessment (COA) questionnaire to determine teachers' priorities related to four different purposes of assessment: (a) improvement of teaching and learning, (b) school accountability, (c) student accountability, and (d) treating assessment as irrelevant. On this instrument, teachers were asked if they agreed or disagreed with various assessment purposes related to these four conceptions. In subsequent research with Ramesal, Brown examined differences in teacher responses to the COA amongst prospective and practicing teachers (Remesal \& Brown, 2012). 
For this sample, they constructed a three-conception model to explain teachers' orientations to assessment: (a) assessment improves, (b) assessment is negative, and (c) assessment shows the quality of schools and students. Across these studies, the COA is used to define teachers primary priorities related to the purposes of assessment with consideration for their values towards assessment practices. The findings from these studies point to a variability in teachers' conceptions of assessment depending upon context and career stage.

Overall, the majority of research on teacher assessment competency employs instruments that aim to determine teachers' orientation towards varying assessment purposes. Results from these studies continue to characterize teachers' assessment competency as largely incongruent with the recommended 1990 Standards (Galluzzo, 2005; Mertler, 2003, 2009; Zhang \& BurryStock, 1997). These findings are concerning given the rapid increase of accountability and assessment-based teaching practices over the past 20 years (Volante \& Fazio, 2007), and especially in light of the recently revised Classroom Assessment Standards (Joint Committee on Standards for Educational Evaluation, 2015). These new standards establish defensible grounds for the development of a new instrument for measuring teacher assessment literacy. In particular, an instrument is required that addresses the contemporary demands on teachers working within the current accountability framework of education and that accounts for the multiple dimensions of assessment literacy beyond solely addressing assessment purposes.

\section{Instrument Development Process}

We used a multi-step development process in order to construct a comprehensive assessment literacy instrument reflective of current assessment standards. Specifically, we (a) engaged in a document analysis of previous and current assessment standards to assist with initial item development, and (b) collected validity evidence to support the intended 
interpretations and uses of the instrument. Of the five sources of validity evidence (i.e., content, response processes, internal structure, relationship to other variables, and consequences) described in the 2014 Standards for Educational and Psychological Testing (AERA, APA, NCME, 2014), this paper presents evidence of validity based on content and internal structure.

\section{Initial Item Development}

Our instrument development process began with a document analysis of 15 assessment standards (1990-present) from five geographic regions (US, Canada, UK, Europe, Australia, and New Zealand) (see DeLuca et al., 2015, for complete analysis of standards). Through this analysis, we identified eight themes representing contemporary aspects of teacher assessment literacy: (a) Assessment Purposes, (b) Assessment Processes, (c) Communication of Assessment Results, (d) Assessment Fairness, (e) Assessment Ethics, (f) Measurement Theory, (g) Assessment for Learning, and (h) Assessment Education and Support for Teachers. For the purpose of developing a reliable yet efficient instrument, we collapsed seven of themes into four:

(a) Assessment Purposes (included aspects of assessment for learning), (b) Assessment Processes (included aspects of communication of assessment results), (c) Assessment Fairness (included aspects of assessment ethics), and (d) Measurement Theory (Table 1). Questions related to these four themes were presented in Part One and Part Two of our instrument. Specifically, Assessment Purposes was coupled with Assessment for Learning, Assessment Processes was coupled with Communication of Assessment Results, and Assessment Fairness was coupled with Assessment Ethics. These themes were coupled for two primary reasons. First, our instrument was intended to reflect contemporary standards in educational assessment as based on the recently published Classroom Assessment Standards (JCSEE, 2015); hence, we logically coupled contemporary themes with previously articulated aspects of assessment literacy. For example, 
Assessment for Learning has emerged as a contemporary aspect of assessment literacy reflecting a newly articulated Assessment Purpose, closely coupled with previous conceptions of formative assessment. Similarly, while contemporary assessment standards articulate the importance of Communication of Assessment Results, this aspect of assessment literacy fits as one stage of the assessment process. Second, in an effort to establish defensible and reliable factors within our instrument whilst balancing the length of the instrument, we elected to focus on four logical themes rather than separating items across seven themes. The eighth theme, Assessment Education and Support for Teachers, was independently represented in Part Three of the instrument and underpins the overarching purpose of this instrument development — to develop an assessment literacy instrument to measure and support teachers' professional learning and practice in classroom assessment.

\section{[Insert Table 1]}

The four collapsed themes were used to develop a three-part instrument to measure teachers': (a) Part One: Approaches to Classroom Assessment; (b) Part Two: Perceived Skill in Classroom Assessment; and (c) Part Three: Assessment Professional Learning Priorities and Preferences. The instrument was titled, the Approaches to Classroom Assessment Instrument (ACAI). We purposefully elected to use terminology related to teachers 'approaches to classroom assessment' for the ACAI rather than 'assessment literacy' or 'assessment competency' for two primary reasons. First, we wanted to ensure that the instrument remained accessible to a wide teacher population and was not jargonistic. Second, 'approaches to classroom assessment' reflects the multiple perspectives and practices that teachers might hold in relation to classroom assessment; whereas, 'assessment literacy' and 'assessment competency' have been associated 
with correct and incorrect assessment knowledge and skills with evaluative underpinnings (Willis, Adie, \& Klenowski, 2013).

\section{Part One: Approaches to Classroom Assessment}

Part One of the ACAI was designed to determine teachers' approaches to classroom assessment. Following Mertler and Campbell $(2004,2005)$ we used a scenario item format; however, unlike previous instruments that presented a multiple-choice correct answer format, each response to our scenarios were viable and reflected differing approaches to classroom assessment as based on assessment standards. The five scenarios represented contemporary assessment dilemmas faced by teachers related to: (a) summative assessment, (b) grading, (c) differentiated assessment, (c) integrated assessment, and (d) standardized assessment. For each scenario, we developed four items in relation to the four assessment literacy themes (i.e., Assessment Purposes, Assessment Processes, Assessment Fairness, and Measurement Theory). Each item had three viable response options that reflected different approaches to classroom assessment (see Table 2). We purposefully developed categorical approaches in keeping with previous research that conceptualized teacher practice in relation to categories and groups (e.g., Brown, 2004; Trigwell \& Prosser, 2004).

\section{[Insert Table 2]}

Approach A focuses on summative approaches to assessment that emphasize reliable assessment design and the standardized administration of assessments of learning across groups. Approach B focuses on formative approaches to assessment that emphasize validity through emphasis on use and scoring of assessments of learning and equitable treatment of students. Approach $\mathrm{C}$ focuses on individualized approaches to assessment that emphasize both reliability 
and validity concerns through communication and a differentiated approach to assessments through assessments as learning.

In total, Part One of the ACAI contained 20 items (i.e., five scenarios with four items for each) corresponding to each of the assessment literacy themes. For each item, teachers were asked to choose from three viable response options based on their individual priorities and approaches to assessment. Part One of the instrument generated a teacher's overall approach to each of the four assessment themes (i.e., Assessment Purposes, Assessment Processes, Assessment Fairness, and Measurement Theory) presenting them with an individual profile of their 'approach to classroom assessment.' Tables 3 to 7 provide blueprints for Part One of the ACAI.

[Insert Tables 3-7]

\section{Part Two: Perceived Skill in Classroom Assessment}

Part Two of the ACAI was designed to determine teachers' perceived skill in relation to contemporary classroom assessment practices. This section of the instrument was directly connected to the Classroom Assessment Standards (JCSEE, 2015). These standards articulate three domains of classroom assessment practice within associated categories: Foundations (F16), Quality (Q1-6), and Use (U1-5). The initial draft of Part Two was comprised of one item per standard, for a total of 17 items (see Table 8 for Part 2 blueprint). In Part Two, teachers were asked to self-assess their current skill level related to each standard on a five-point scale (1=novice, 2 =beginner, $3=$ proficient, $4=$ competent, and $5=$ =xpert).

[Insert Table 8]

Part Three: Assessment Professional Learning Priorities and Preferences 
Based on the theme, Assessment Education and Support for Teachers, Part Three of the ACAI was designed to determine teachers' professional learning priorities and preferences in assessment. Part Three (A) of the initial instrument was comprised of eight professional learning priorities based on the themes from our analysis of assessment standards (see DeLuca et al., 2015). Teachers were asked to prioritize their interest in learning about identified aspects of classroom assessment using a Likert-type scale ( $1=$ very low interest; $5=$ very high interest) (see Table 9). We also identified common modes of teacher professional learning based on previous literature. Seven modes were included in Part Three (B) of the draft instrument (e.g., face-to-face courses, online courses, and job-embedded models). Teachers were asked to indicate their preferred modes of professional learning using a Likert-type scale ( $1=$ not preferred; $5=$ highly preferred) (see Table 10). Combined, the items in Part Three were intended to guide professional development efforts by identifying priority areas for teacher learning as well as preferred modes for that learning.

[Insert Tables 9-10]

\section{Evidence of Validity Based on Content: Expert-Panel Review}

An expert-panel method was used to collect construct validity evidence for the ACAI. Invitations to review the assessment literacy instrument were emailed to 24 North American educational assessment experts. Experts were recruited based on the following criteria: (a) membership in the Canadian Education Researchers' Association or National Council on Measurement in Education; (b) published in the area of classroom or large-scale assessment; and/or (c) an active member of a university, school district, or education/assessment-related institution. Ten experts meeting these criteria agreed to participate. The ten experts ranged in age from 38-70 years old and were all affiliated with a university or college in Canada or the United 
States. Assessment experts were drawn from the provinces of Alberta, British Columbia, Nova Scotia, and Ontario, and from Florida, Virginia, and Kentucky in the United States. All experts had peer-reviewed publications in the areas of testing or educational assessment. In addition, the majority of experts had served as editors, editorial board members, or executive members of professional association (i.e., National Council on Measurement in Education, Canadian Educational Researchers' Association) in the area of measurement, evaluation, and assessment. In addition to an educational assessment expert panel, we invited 10 classroom teachers (five elementary and five secondary) to serve as a practitioner expert panel. Classroom teachers ranged in age from 32 to 54 years old with between 8 and 31 years of classroom teaching experience. All teachers had completed a pre-service teacher education program and were currently certified teachers in Ontario. Three teachers had earned a Masters degree in the field of Education. All panelists reviewed the instrument using the same protocol.

Each expert participant was sent the assessment literacy instrument with review instructions via email. An alignment methodology was used to guide the expert review process (DeLuca \& Bellara, 2013; Webb, 1997, 1999, 2005). For Part One: Approaches to Classroom Assessment, experts were asked to double rate each response option based on its (a) alignment to the identified assessment literacy theme, and (b) alignment to the identified assessment priority (see Tables 3-7). A rating-scale was used for alignment ratings ( $1=$ not aligned to $5=$ strongly aligned). For items with overall average ratings of three or below, experts were asked to: (a) explain their rating rationale, and (b) suggest alternative response options. In addition to alignment ratings, experts were asked to suggest revisions to the five assessment scenarios that comprised Part One of the instrument.

For Part Two: Perceived Skill in Assessment, experts were asked to indicate whether 
each item reflected the complexity, depth, and range (DeLuca \& Bellara, 2013) of the associated theme (i.e., yes or no) and suggest revisions as appropriate. For Part Three (A): Assessment Professional Learning Priorities, experts were asked if the items represented the complexity, depth, and range of assessment competency (i.e., yes or no) and instructed to suggest revisions as appropriate. For Part Three (B): Assessment Professional Learning Preferences, experts were asked to suggest additional modes of professional learning that were not included in the draft instrument. Experts were asked to participate in up to three rounds of review, until all items in Part One received overall average ratings of four or five and all items in Parts Two and Three received complete 'yes' responses. Once all items meet these criteria, the instrument was pilot tested with over 400 teachers.

\section{Expert-Panel Results}

Based on feedback from experts, several revisions were made to the assessment literacy instrument. For each response option in Part One, we calculated the percentage of expert alignment ratings over 3 . Thirteen of the 20 items had response options with less than 60 percent of expert ratings over 3. In total, 19 response options were rewritten to incorporate expert feedback and to better align with the intended assessment theme and/or priority. Of the five scenarios presented in Part One, Scenario 2 was changed to make the assessment dilemma applicable to a broader range of K-12 teachers, and Scenarios 3 and 4 were changed slightly to clarify wording.

For Part Two of the ACAI, experts agreed that the 17 items in the draft instrument aligned with the designated standards (JCSEE, 2015). Based on expert feedback, the 17 items were expanded to 26 items to avoid double-barreled items (see Table 8).

For Part Three (A), experts agreed that each of the eight items aligned with the 
designated assessment literacy theme. Based on expert feedback, the eight items were expanded to twelve to avoid double-barreled items (see Table 9). In addition, Part Three (B) was expanded from seven to fourteen modes of learning based on expert feedback (see Table 10)

\section{Evidence Based on Internal Structure: Pilot Testing}

\section{Sample}

A survey method was used to collect validity evidence based on internal structure. Participants completed the ACAI through an electronic invitation posted on various social and media networks. The sample consisted of 404 Canadian teachers who completed the ACAI in Spring 2015. Participants reflected diverse demographic groupings. The sample included 63\% in-service teachers and $37 \%$ pre-service teachers. In terms of gender and age distributions, the sample included $84 \%$ females and $16 \%$ males; $35 \%$ were between 20 and 25 years of age, $36 \%$ were between 26 and 35 years of age, and $28 \%$ were over 36 years old. In terms of K-12 teaching context, participants worked in Public (66\%), Catholic (14\%), and Independent (20\%) schools.

\section{Analysis}

Part One: Approaches to Classroom Assessment contained 20 items organized into five scenarios. Each scenario had an item corresponding to each of the four assessment themes (i.e., Assessment Purposes, Assessment Processes, Assessment Fairness, and Measurement Theory). Given the categorical nature of item response options, to generate a teacher's overall approach to each assessment theme, mode statistics were calculated as measures of central tendency across scenarios. Furthermore, due to the categorical nature of response options, traditional correlationbased internal consistency estimates were inappropriate measures of internal structure. Consequently, as a proxy measure of consistency, Pearson's Chi-square tests were used to 
examine whether response patterns (mode statistics) were consistent across demographic groupings (i.e., gender, age, and teaching context).

Part Two: Perceived Skill in Classroom Assessment contained 26 items presumed to be ordinal, measured on a five-point scale ( $1=$ novice, $2=$ beginner, $3=$ proficient, $4=$ competent, and $5=$ expert), designed to determine teachers' perceived skill in relation to contemporary classroom assessment practices. Principal component analysis with promax (oblique) rotation was used to generate subscales out of the 26 items. The Kaiser-Meyer-Olkin (KMO) measure was used to verify the sampling adequacy for the analysis. Items were retained in a subscale if they did not have double loadings and improved the overall reliability of the factor while retaining high factor loadings and KMO values. Resulting subscale means and standard deviations were then calculated and Cronbach's alpha, $\alpha$, used to calculate the internal consistency of each resulting subscale.

Part Three: Assessment Professional Learning Priorities and Preferences contained two sections, used to determine teachers' professional learning priorities and preferences in assessment. Part Three (A) contained 12 ordinal items that asked teachers to prioritize their interest in learning about identified aspects of classroom assessment using a Likert-type scale ( $1=$ very low interest; $5=$ very high interest). Part Three (B) contained 14 ordinal items that asked teachers to indicate their preferred modes of professional learning using a Likert-type scale ( $1=$ not preferred; $5=$ highly preferred). Subscales for each section were generated following the same guidelines as those used for Part Two. Resulting subscale means and standard deviations were then calculated and Cronbach's alpha, $\alpha$, used to calculate the internal consistency of each resulting subscale.

\section{Results}


Part One: Approaches to Classroom Assessment. Table 11 reports the frequency distributions of response options by gender, age, and teaching context (i.e., K-12 employment system), respectively. Across demographic groupings, the modal value for Assessment Purpose was Assessment for Learning; the modal values for Assessment Processes were Design and Communication; the modal value for assessment Fairness was Differentiated approach; and the modal value for Measurement Theory was Reliability and Validity. Results of Pearson's Chisquare tests indicated there were no statistically significant differences in overall theme response patterns across demographic groupings.

\section{[Insert Table 11]}

Part Two: Perceived Skill in Classroom Assessment. Principal component analysis resulted in a reduction from 26 to 12 items (Table 12). Two subscales were identified: Monitoring, Analyzing, and Communicating Assessment Results which contained seven items and Assessment Design, Implementation, and Feedback which contained five items. Table 13 provides the item and subscale means and standard deviations for the Monitoring, Analyzing, and Communicating Assessment Results subscale and the Assessment Design, Implementation, and Feedback subscale. The correlation between subscales was 0.71 and the internal consistency estimates for the subscales were found to be $\alpha=.90$ and $\alpha=.89$, respectively.

[Insert Table 12-13]

Part Three: Assessment Professional Learning Priorities and Preferences. In Part Three - A: Assessment Professional Learning Priorities, the principal component analysis resulted in a reduction from 12 to 10 items (Table 14). Two subscales were identified: Integrating and Communicating Assessment Practices which contained six items and Alignment with Current Assessment Theory, Principles, and Practices which contained four items. Table 15 
provides the item and subscale means and standard deviations for the Integrating and Communicating Assessment Practices subscale and the Alignment with Current Assessment Theory, Principles, and Practices subscale. The correlation between subscales was 0.50 and the internal consistency estimates for the subscales were found to be $\alpha=.83$ and $\alpha=.85$, respectively.

[Insert Table 14-15]

In Part Three - B, Assessment Professional Learning Preferences, the principal component analysis resulted in a reduction from 14 to 11 items (Table 16). Three subscales were identified: Online Learning which contained five items, Face-to-Face, Group Learning which contained four items, and One-on-One Learning which contained two items. Table 17 provides the item and subscale means and standard deviations for each subscale. The correlations between subscales ranged from 0.04 to 0.42 (Table 18) and the internal consistency estimates for the subscales were found to be $\alpha=.86, \alpha=.74$ and $\alpha=.92$, respectively.

[Insert Table 16-18]

\section{Future Directions}

We conducted this research in response to Gotch and French's (2014) call to develop a reliable instrument to measure teacher's assessment literacy that represented current demands within the existing assessment landscape. The ACAI was developed to reflect contemporary practices for classroom assessment that were explicitly predicated on the newly published Classroom Assessment Standards (JCSEE, 2015). Our developmental process for the ACAI provided initial construct validity evidence through an expert panel of teachers and assessment specialists following an alignment methodology (Authro; Webb, 1997, 1999, 2005). Reliability statistics were also derived from pilot testing with more than 400 pre-service and in-service teachers. Given the significant transformations in classroom assessment practices over the past 
several decades, and the importance of assessment within the current accountability paradigm of education, we assert that the ACAI provides a new and needed instrument to support research and professional development in the area of assessment literacy. Accordingly, in this final section, we identify the implications of the ACAI on future research and teacher professional learning.

\section{Implications for Assessment Research}

This paper presents our research on the development and initial application of the ACAI, providing a basis for future research in the area teacher assessment literacy. We assert that given the geographic boundaries of our sample population, additional empirical testing and subsequent refinement of the ACAI are required. Using the ACAI with teachers (pre-service and in-service) in other jurisdictions will provide data for continued refinement of the instrument to reflect terminology and concepts relevant to other educational systems.

Beyond providing additional validity and reliability evidence for the ACAI, we see value in using the ACAI to further promote research into teachers' assessment literacy. In particular, the following agenda could stem from research using the ACAI:

- Supporting data-informed professional learning in classroom assessment. Research is needed on how the ACAI, or other indicators of teacher assessment literacy, could be used to support the selection and monitoring of teacher learning goals related to classroom assessment. For example, individual and systemic data collected through the ACAI could provoke collaborative inquiries for teacher learning or support school and district professional learning initiatives (e.g., workshops, expert support, resources). We assert that there is value in future research that tracks how teachers use data about their own assessment literacy to guide their professional learning in assessment, and how 
regions and districts use data on teachers' approaches to assessment to direct systemic professional development resources.

- Mapping teachers' approaches to classroom assessment. Given the growing focus on classroom assessment across educational systems, the need exists to better understand how teachers conceptualize and practice classroom assessment in relation to contemporary standards. The ACAI provides an instrument to construct baseline data on teachers' approaches to classroom assessment_ an important initiative given the rapidly evolving landscape of education assessment. Researching how teachers' orientations to assessment shift from pre-service to in-service, and across years of experience, will also provide important information on the development of teachers' assessment literacy over their careers. These foundational data can then be compared across districts and systems in order to direct professional development resources towards focused priorities responsive to teachers' approaches to assessment and career stage.

- Linking teacher's approaches to assessment with their perceived skill and professional learning priorities. In order to support teachers' learning in assessment, we assert that it is critical to understand the intersection between teachers' current approaches to assessment, their perceived perceived skill in diverse aspects of assessment practice, and their professional learning priorities and preferences in assessment. Combined, these aspects will not only direct what teachers need to learn in assessment but also provide important information on the preferred mode for professional development. Accordingly, we see value in researching how these three aspects are supported in practice and how teachers' interests and preferences change over time and in relation to transformations in the assessment landscape. The ACAI provides a tool for researchers to begin to track 
these aspects of teacher assessment literacy and supports ongoing efforts towards responsive teacher education in this area.

- Reconceptualizing assessment literacy. We deliberately used terminology related to 'approaches to classroom assessment' rather than 'assessment literacy' or 'assessment competency' in the ACAI because we support the notion that teachers' assessment skills and knowledge are socially and contextually dependent (Willis et al., 2013). Unlike previous assessment literacy measures (e.g., Mertler, 2003; Plake, et al., 1999), there are no correct responses to ACAI scenarios. Instead, we recognize teachers' diverse approaches to assessment and would encourage teachers to critically evaluate their approaches in light of other response options to ensure that their actions align with their personal intentions and the intentions of educational policies. Accordingly, following other scholars (e.g., Willis et al., 2013), we assert the need to reconceptualize assessment literacy as a developmental process that is mediated by context, opportunity to learn, personal preferences, and school/system culture. As future research continues to investigate teachers' approaches to assessment, there is simultaneously a need to explore how teachers develop fluency in assessment based on their context of practice and exposure to responsive teacher education.

\section{Implications for Teacher Professional Learning}

Further to supporting a research agenda in the area of assessment literacy development, the ACAI provides a basis for directing teacher assessment education. Based on our initial results from pilot testing with over 400 teachers, there is evidence to suggest that not all teachers value the same approach to professional learning or maintain the same learning goals in assessment. Therefore, the practical implications of our research provide the foundation for developing 
differentiated and targeted professional learning based on teachers' identified approaches to assessment, areas of perceived skill, and professional development priorities and preferences. In particular, differentiated professional development may be required by teacher career stage (e.g., pre-service vs. in-service), orientation to assessment, teacher learning goals in assessment, or teachers' preferred mode of professional learning at individual, school, board, and regional levels.

Further to providing diagnostic information on teachers' approaches to assessment as a basis for differentiated and targeted professional development, we propose using the ACAI to support continued monitoring of teachers' changing approaches to assessment in relation to assessment education. Moreover, the scenarios depicted in the ACAI could serve as initial conversation starters to provoke teacher dialogue and collaborative inquiries into classroom assessment theory and practice. While reporting empirical results on the utility of the ACAI for these professional learning processes is beyond the scope of this paper, we intend to purse these practical implications in our subsequent work in efforts to enhance teachers' assessment fluency through a data-informed professional learning model.

\section{Conclusion}

Over the past two decades, teacher assessment literacy has been a growing area in assessment research. While previous inventories and surveys of teacher assessment literacy have stimulated much of this research, several scholars have noted that these instruments are now outdated and do not reflect teachers' contemporary assessment demands (Brookhart, 2011; DeLuca et al., 2015; Gotch \& French, 2014). The ACAI provides a new instrument to support research and professional development in the area of teacher assessment literacy. This study has provided initial validity and reliability evidence to support the ACAI as a useful indicator of 
teachers' approaches to classroom assessment, their perceived skill in relation to contemporary assessment tasks, and their priorities and preferences for professional learning. Combined, information obtained from the ACAI can provoke critical research into teachers' current assessment literacy levels as well as a database for targeted professional learning. Accordingly, through this paper, we present the ACAI as a tool for use and refinement by researchers and educational practitioners in the service of enhancing teachers' assessment literacy. 


\section{Reference}

America Educational Research Association, American Psychological Association, \& National Council on Measurement in Education. [AERA, APA, NCME]. (2014). Standards for educational and psychological testing. Washington, DC: American Psychological Association.

American Federation of Teachers, National Council on Measurement in Education, \& National Education Association (1990). Standards for teacher competence in educational assessment of students. Washington, DC: National Council on Measurement in Education.

Brookhart, S. (2011). Educational assessment knowledge and skills for teachers. Educational Measurement: Issues and Practice, 30, 3-12.

Brown, G. T. (2004). Teachers' conceptions of assessment: Implications for policy and professional development. Assessment in Education: Principles, Policy \& Practice, 11(3), 301-318.

Campbell, C., Murphy, J. A., \& Holt, J. K. (2002, October). Psychometric analysis of an assessment literacy instrument: Applicability to pre-service teachers. Paper presented at the annual meeting of the Mid-Western Educational Research Association, Columbus, $\mathrm{OH}$.

Crocker, L., \& Algina, J. (2006). Introduction to classical and modern test theory. Belmont, CA: Wadsworth.

DeLuca, C., \& Bellara, A. (2013). The current state of assessment education aligning policy, standards, and teacher education curriculum. Journal of Teacher Education, 64(4), 356372. 
DeLuca, C., LaPointe-McEwan, D., \& Luhanga, U. (2015). Teacher assessment literacy: a review of international standards and measures. Educational Assessment, Evaluation and Accountability, 1-22.

Galluzzo, G. R. (2005). Performance assessment and renewing teacher education. Clearing House, 78(4), 142-45.

Gotch, C. M., \& French, B. F. (2014). A systematic review of assessment literacy measures. Educational Measurement: Issues and Practice, 33, 14-18.

Joint Committee for Standards on Educational Evaluation. (2015). Classroom assessment standards: Practices for PK-12 teachers. Retrieved from http://www.jcsee.org/theclassroom-assessment-standards-new-standards

Mertler, C. A. (2003). Pre-service versus in-service teachers' assessment literacy: Does classroom experience make a difference? In Annual meeting of the Mid-Western Educational Research Association, Columbus, $\mathrm{OH}$.

Mertler, C. A. (2009). Teachers' assessment knowledge and their perceptions of the impact of classroom assessment professional development. Improving Schools, 12(2), 101-113. doi:10.1177/1365480209105575

Mertler, C. A. (2004). Secondary teachers' assessment literacy: Does classroom experience make a difference?. American Secondary Education, 49-64.

Mertler, C. A., \& Campbell, C. (2005). Measuring Teachers' Knowledge \& Application of Classroom Assessment Concepts: Development of the Assessment Literacy Inventory. In Annual meeting of the American Educational Research Association, Montreal, QC. 
O’Sullivan, R. S., \& Johnson, R. L. (1993, April). Using performance assessments to measure teachers' competence in classroom assessment. Paper presented at the annual meeting of the American Educational Research Association, Atlanta, GA.

Plake, B., Impara, J., \& Fager, J. (1993). Assessment competencies of teachers: A national survey. Educational Measurement: Issues and Practice, 12(4), 10-39. doi:10.1111/j.17453992.1993.tb00548.x

Popham, W. J. (2013). Classroom assessment: What teachers need to know (7th ed.). Boston, MA: Pearson.

Trigwell, K., \& Prosser, M. (2004). Development and use of the approaches to teaching inventory. Educational Psychology Review, 16(4), 409-424.

Volante, L., \& Fazio, X. (2007). Exploring teacher candidates' assessment literacy: Implications for teacher education reform and professional development. Canadian Journal of Education, 30, 749-770.

Webb, N. L. (1997). Criteria for alignment of expectations and assessments in mathematics and science education. Washington, DC: Council of Chief State School Officers.

Webb, N. L. (1999). Alignment of science and mathematics standards and assessments in four states. Washington, DC: Council of Chief State School Officers.

Webb, N. L. (2005). Webb alignment tool: Training manual. Madison: Wisconsin Center for Education Research. Retrieved from http://www.wcer.wisc.edu/WAT/index.aspx

Willis, J., Adie, L., \& Klenowski, V. (2013). Conceptualising teachers' assessment literacies in an era of curriculum and assessment reform. The Australian Educational Researcher, $40(2), 241-256$. 
Zhang, Z., \& Burry-stock, J. A. (1997). Assessment Practices Inventory: A multivariate analysis of teachers' perceived assessment competency. In Annual meeting of the American Educational Research Association, Chicago, IL. 
Table 1

Collapsed Assessment Literacy Themes

\begin{tabular}{ll}
\hline Collapsed Assessment Theme & \multicolumn{1}{c}{ Theme Descriptions from Initial Analysis of Standards } \\
\hline Assessment Purpose & $\begin{array}{l}\text { Assessment Purposes: Choosing the appropriate form of } \\
\text { assessment based on instructional goals. }\end{array}$ \\
& $\begin{array}{l}\text { Assessment for Learning: Using formative assessment during } \\
\text { instruction to guide next steps in teaching and learning. }\end{array}$ \\
Assessment Process & $\begin{array}{l}\text { Assessment Processes: Constructing, administering, and } \\
\text { scoring assessments. Interpreting assessment results to } \\
\text { facilitate instructional decision-making. }\end{array}$ \\
& $\begin{array}{l}\text { Communication of Assessment Results: Communicating } \\
\text { assessment purposes, processes, and results to students, } \\
\text { parents/guardians, and other stakeholders. }\end{array}$ \\
Assessment Fairness & $\begin{array}{l}\text { Assessment Fairness: Cultivating fair assessment conditions } \\
\text { for all learners, with sensitivity to student diversity and } \\
\text { exceptional learners. }\end{array}$ \\
& $\begin{array}{l}\text { Assessment Ethics: Disclosing accurate information about } \\
\text { assessments. Protecting the rights and privacy of students that } \\
\text { are assessed. }\end{array}$ \\
Measurement Theory: Understanding psychometric \\
properties of assessments (e.g., reliability and validity).
\end{tabular}


Table 2

Assessment Literacy Themes with associated Approaches to Assessment

\begin{tabular}{lccc}
\hline \multirow{2}{*}{$\begin{array}{c}\text { Assessment Literacy } \\
\text { Theme }\end{array}$} & Approach A & Approach B & Approach C \\
\cline { 2 - 4 } & Assessment of Learning & Assessment for Learning & Assessment as Learning \\
Assessment Purposes & Design & Use/Scoring & Communication \\
Assessment Processes & Standard treatment & Equitable treatment & Differentiated approach \\
Assessment Fairness & Reliability & Validity & Reliability/Validity \\
Measurement Theory & & & \\
\hline
\end{tabular}


Table 3

Survey Blueprint for Part One: Approaches to Classroom Assessment - Scenario 1

Scenario: You give your class a paper-pencil summative unit test with accommodations and modifications for identified learners. Sixteen of the 24 students fail. As a teacher in this situation, your ideal priority would be to:

\begin{tabular}{|c|c|c|}
\hline $\begin{array}{l}\text { Assessment } \\
\text { Literacy Theme }\end{array}$ & $\begin{array}{l}\text { Approach to } \\
\text { Assessment }\end{array}$ & Response Options \\
\hline \multirow[t]{3}{*}{$\begin{array}{l}\text { Assessment } \\
\text { Purposes }\end{array}$} & AoL & $\begin{array}{l}\text { Record the test grade as each student's summative assessment for the unit but reduce its weight in the } \\
\text { final grade. }\end{array}$ \\
\hline & AfL & $\begin{array}{l}\text { Based on your analysis of the test, reteach parts of the unit focusing on items students struggled with, } \\
\text { give students opportunities to apply their learning, and then re-test the material. }\end{array}$ \\
\hline & $\mathrm{AaL}$ & $\begin{array}{l}\text { Ask students to reflect on their test preparation, analyze their test responses, and make a personal } \\
\text { learning plan for re-learning the material. Then re-test the material. }\end{array}$ \\
\hline \multirow{3}{*}{$\begin{array}{l}\text { Assessment } \\
\text { Processes }\end{array}$} & Design & Recognize that your test design may be flawed and design a revised unit test to give students. \\
\hline & Use/Scoring & Remove test questions that most students failed and re-calculate students scores without those questions. \\
\hline & Communication & Schedule student conferences (individual or group) to discuss grades, areas of confusion, and next steps. \\
\hline \multirow{3}{*}{$\begin{array}{l}\text { Assessment } \\
\text { Fairness }\end{array}$} & Standard & Allow all students to retake a similar test and average the two grades. \\
\hline & Equitable & $\begin{array}{l}\text { Ensure students with identified learning exceptionalities retake a similar test and take the better of the } \\
\text { two grades. }\end{array}$ \\
\hline & Differentiated & $\begin{array}{l}\text { Have each student who failed the test negotiate with you a new task/activity that would appropriately } \\
\text { demonstrate their learning. }\end{array}$ \\
\hline \multirow[t]{3}{*}{$\begin{array}{l}\text { Measurement } \\
\text { Theory }\end{array}$} & Reliability & $\begin{array}{l}\text { Analyze test questions that the majority of students consistently answered incorrectly. Then provide } \\
\text { students with new questions to test those concepts. }\end{array}$ \\
\hline & Validity & $\begin{array}{l}\text { Consider student test scores in light of previous, formative assessment information available for each } \\
\text { student. Consider this information and adjust grades accordingly. }\end{array}$ \\
\hline & $\begin{array}{l}\text { Reliability/ } \\
\text { Validity }\end{array}$ & $\begin{array}{l}\text { Reflect on which students failed, considering wording of test items and extenuating circumstances that } \\
\text { may have contributed to the failure in relation to previous assessment information. Then adjust grades } \\
\text { accordingly. }\end{array}$ \\
\hline
\end{tabular}

Note. AoL $=$ Assessment of learning; AfL = Assessment for learning; AaL = Assessment as learning. 
Table 4

Survey Blueprint for Part One: Approaches to Classroom Assessment-Scenario 2

Scenario: You discover that one of your students has plagiarized some of his assignment (i.e., an essay). As a teacher in this situation, your ideal priority would be to:

\begin{tabular}{|c|c|c|}
\hline $\begin{array}{l}\text { Assessment } \\
\text { Literacy Theme }\end{array}$ & $\begin{array}{l}\text { Approach to } \\
\text { Assessment }\end{array}$ & Response Options \\
\hline \multirow{3}{*}{$\begin{array}{l}\text { Assessment } \\
\text { Purposes }\end{array}$} & AoL & Administer consequences in alignment with school policies on plagiarism. \\
\hline & AfL & $\begin{array}{l}\text { Have him highlight the plagiarized text and then rewrite the section in his own words. As a teacher, } \\
\text { reflect on how this incident might inform your future teaching practice. }\end{array}$ \\
\hline & $\mathrm{AaL}$ & $\begin{array}{l}\text { Ask him to document how he obtained and used reference materials for the assignment and what he } \\
\text { would do differently next time. Have him write a work plan for re-doing the assignment. }\end{array}$ \\
\hline \multirow[t]{3}{*}{$\begin{array}{l}\text { Assessment } \\
\text { Processes }\end{array}$} & Design & $\begin{array}{l}\text { Reflect on how you as a teacher designed and presented the assignment. In the future ensure that you } \\
\text { deliberately design opportunities for students to learn about plagiarism. }\end{array}$ \\
\hline & Use/Scoring & Grade the aspects of student work that are original and deduct grades for the plagiarize sections. \\
\hline & Communication & Talk with him about the severity of plagiarism and negotiate potential next steps for his learning. \\
\hline \multirow[t]{3}{*}{$\begin{array}{l}\text { Assessment } \\
\text { Fairness }\end{array}$} & Standard & $\begin{array}{l}\text { Explain to him the policy on plagiarism and how you could consistently apply the policy so that it is fair } \\
\text { for all students. }\end{array}$ \\
\hline & Equitable & $\begin{array}{l}\text { Consider his specific learning needs and exceptionalities before determining whether or not to apply the } \\
\text { general plagiarism policy. }\end{array}$ \\
\hline & Differentiated & $\begin{array}{l}\text { Conference with him to review the implications of plagiarizing and agree upon an appropriate alternate } \\
\text { assignment. }\end{array}$ \\
\hline \multirow{3}{*}{$\begin{array}{l}\text { Measurement } \\
\text { Theory }\end{array}$} & Reliability & Consistently apply a grade of zero to the plagiarized work. \\
\hline & Validity & $\begin{array}{l}\text { Consider the original aspects of the assignment and the plagiarized text to determine what he knows and } \\
\text { does not appear to know about the content expectations. }\end{array}$ \\
\hline & $\begin{array}{l}\text { Reliability/ } \\
\text { Validity }\end{array}$ & $\begin{array}{l}\text { Examine extenuating circumstances that led to the plagiarism and then develop an alternative assignment } \\
\text { to assess the expectations relevant to the plagiarized section of the assignment. }\end{array}$ \\
\hline
\end{tabular}

Note. $\mathrm{AoL}=$ Assessment of learning; $\mathrm{AfL}=$ Assessment for learning; $\mathrm{AaL}=$ Assessment as learning. 


\section{Table 5}

Survey Blueprint for Part One: Approaches to Classroom Assessment-Scenario 3

Scenario: Out of 28 students in your class, you have 4 identified students on Individualized Education Plans (IEP) (who require accommodations but not modified curriculum) as well as several other unidentified students with differentiated learning needs. You must decide how to accurately measure their learning in your class. As a teacher in this situation, your ideal priority would be to:

\begin{tabular}{|c|c|c|}
\hline $\begin{array}{l}\text { Assessment } \\
\text { Literacy Theme }\end{array}$ & $\begin{array}{l}\text { Approach to } \\
\text { Assessment }\end{array}$ & Response Options \\
\hline \multirow{3}{*}{$\begin{array}{l}\text { Assessment } \\
\text { Purposes }\end{array}$} & AoL & Provide the 4 identified students with accommodations on all summative assessments. \\
\hline & AfL & $\begin{array}{l}\text { Implement scaffolded formative assessments with all of your students based on their individual learning } \\
\text { needs, leading up to the final accommodated unit test. }\end{array}$ \\
\hline & $\mathrm{AaL}$ & $\begin{array}{l}\text { Allow each student to develop a personal learning plan based on his/her strengths, learning needs, and } \\
\text { the learning goals. }\end{array}$ \\
\hline \multirow[t]{3}{*}{$\begin{array}{l}\text { Assessment } \\
\text { Processes }\end{array}$} & Design & $\begin{array}{l}\text { Design a variety of assessment tasks that allow students to choose how they will demonstrate their } \\
\text { achievement of learning expectations. }\end{array}$ \\
\hline & Use/Scoring & Adjust your rubrics and scoring guides to reflect accommodated and modified programs. \\
\hline & Communication & $\begin{array}{l}\text { Explain to students and parents the purpose of accommodations and how they will be implemented and } \\
\text { communicated on students' report cards. }\end{array}$ \\
\hline \multirow{3}{*}{$\begin{array}{l}\text { Assessment } \\
\text { Fairness }\end{array}$} & Standard & Grade students based on the same assessments including homework, quizzes, and a unit test. \\
\hline & Equitable & $\begin{array}{l}\text { Ensure students with identified learning exceptionalities are provide with accommodations on all } \\
\text { assessment tasks. }\end{array}$ \\
\hline & Differentiated & Negotiate differentiated assessments for all students based on their individual learning needs. \\
\hline \multirow{3}{*}{$\begin{array}{l}\text { Measurement } \\
\text { Theory }\end{array}$} & Reliability & Use the same scoring rubric for all students. \\
\hline & Validity & Develop different scoring rubrics for identified students. \\
\hline & $\begin{array}{l}\text { Reliability/ } \\
\text { Validity }\end{array}$ & $\begin{array}{l}\text { Use the same scoring rubric for all students but use professional judgment to apply criteria differently } \\
\text { based on individual student ability. }\end{array}$ \\
\hline
\end{tabular}

Note. $\mathrm{AoL}=$ Assessment of learning; $\mathrm{AfL}=$ Assessment for learning; AaL $=$ Assessment as learning. 
Table 6

Survey Blueprint for Part One: Approaches to Classroom Assessment-Scenario 4

Scenario: You are planning a unit for your class. As a teacher in this situation, your ideal priority would be to:

\begin{tabular}{|c|c|c|}
\hline $\begin{array}{l}\text { Assessment } \\
\text { Literacy Theme }\end{array}$ & $\begin{array}{l}\text { Approach to } \\
\text { Assessment }\end{array}$ & Response Options \\
\hline \multirow{3}{*}{$\begin{array}{l}\text { Assessment } \\
\text { Purposes }\end{array}$} & AoL & Start by designing a summative evaluation and use backward planning to create your lesson plans. \\
\hline & AfL & $\begin{array}{l}\text { Design formative assessments to be used during instruction. Use information from these assessments to } \\
\text { guide the design of subsequent lessons, learning activities, and summative assessment tasks. }\end{array}$ \\
\hline & $\mathrm{AaL}$ & $\begin{array}{l}\text { Start by reviewing the curriculum learning expectations with students and require each student to } \\
\text { develop and negotiate a personal learning and assessment plan for the unit of study. }\end{array}$ \\
\hline \multirow{3}{*}{$\begin{array}{l}\text { Assessment } \\
\text { Processes }\end{array}$} & Design & Design a summative evaluation that covers all relevant curriculum expectations for the unit. \\
\hline & Use/Scoring & $\begin{array}{l}\text { Consult school policy to decide how homework, quizzes, and the summative evaluation will be weighted } \\
\text { in the overall grade for the unit. }\end{array}$ \\
\hline & Communication & Co-construct learning goals and discuss assignments and grading criteria for the unit with your students. \\
\hline \multirow[t]{3}{*}{$\begin{array}{l}\text { Assessment } \\
\text { Fairness }\end{array}$} & Standard & $\begin{array}{l}\text { Plan class lessons and assessments that are the same for all students and encompass the curriculum } \\
\text { expectations. }\end{array}$ \\
\hline & Equitable & $\begin{array}{l}\text { Give all students a diagnostic assessment at the beginning of the unit to group students for differentiated } \\
\text { learning and assessment activities. }\end{array}$ \\
\hline & Differentiated & $\begin{array}{l}\text { Give all students a diagnostic assessment at the beginning of the unit and have students use their results } \\
\text { to select appropriate learning and assessment activities. }\end{array}$ \\
\hline \multirow{3}{*}{$\begin{array}{l}\text { Measurement } \\
\text { Theory }\end{array}$} & Reliability & Use the professional developed quizzes and unit test provided in the teacher's guide. \\
\hline & Validity & Develop assessments based on the content and activities of your enacted lessons. \\
\hline & $\begin{array}{l}\text { Reliability/ } \\
\text { Validity }\end{array}$ & $\begin{array}{l}\text { Develop assessments based on questions/activities that have worked well with other students like yours } \\
\text { but adjust them to take into consideration the content and activities of your enacted lessons. }\end{array}$ \\
\hline
\end{tabular}

Note. $\mathrm{AoL}=$ Assessment of learning; $\mathrm{AfL}=$ Assessment for learning; $\mathrm{AaL}=$ Assessment as learning. 
Table 7

Survey Blueprint for Part One: Approaches to Classroom Assessment - Scenario 5

Scenario: A parent of one of your identified students is concern about an upcoming standardized test. As a teacher in this situation, your ideal priority would be to:

\begin{tabular}{|c|c|c|}
\hline $\begin{array}{l}\text { Assessment } \\
\text { Literacy Theme }\end{array}$ & $\begin{array}{l}\text { Approach to } \\
\text { Assessment }\end{array}$ & Response Options \\
\hline \multirow[t]{3}{*}{$\begin{array}{l}\text { Assessment } \\
\text { Purposes }\end{array}$} & AoL & $\begin{array}{l}\text { Standardized testing provides an important measure of how the school system is working for all students } \\
\text { and the results allow school districts to invest resources into schools where improvement is needed. }\end{array}$ \\
\hline & AfL & $\begin{array}{l}\text { Standardized tests can provide feedback on students' learning towards educational standards and help } \\
\text { guide teaching and learning. }\end{array}$ \\
\hline & $\mathrm{AaL}$ & $\begin{array}{l}\text { The standardized test will provide students an opportunity to develop learning strategies, test-preparation } \\
\text { skills, and goals for their learning. }\end{array}$ \\
\hline \multirow[t]{3}{*}{$\begin{array}{l}\text { Assessment } \\
\text { Processes }\end{array}$} & Design & $\begin{array}{l}\text { Prior to testing, all students will complete practice tests to prepare and become familiar with the } \\
\text { standardized test. }\end{array}$ \\
\hline & Use/Scoring & $\begin{array}{l}\text { Standardized test results will not be incorporated into her child's report card grades but will facilitate } \\
\text { instructional decisions regarding subsequent courses or programs. }\end{array}$ \\
\hline & Communication & $\begin{array}{l}\text { The purpose of standardized testing will be explained in detail to all students prior to testing and results } \\
\text { explained to students and parents. }\end{array}$ \\
\hline \multirow{3}{*}{$\begin{array}{l}\text { Assessment } \\
\text { Fairness }\end{array}$} & Standard & All eligible students in the class must write the standardized assessment. \\
\hline & Equitable & Her child's IEP will be consulted prior to testing and appropriate accommodations will be provided. \\
\hline & Differentiated & $\begin{array}{l}\text { Discuss with the parent why standardized tests are required and how classroom assessments enable } \\
\text { greater differentiation. }\end{array}$ \\
\hline \multirow[t]{3}{*}{$\begin{array}{l}\text { Measurement } \\
\text { Theory }\end{array}$} & Reliability & $\begin{array}{l}\text { Standardized assessments are designed to provide a measure of students' achievement across the school } \\
\text { district. }\end{array}$ \\
\hline & Validity & $\begin{array}{l}\text { Report card grades allow parents to draw more valid conclusions about their child's growth and } \\
\text { achievement of expectations that are grounded in the curriculum and prioritized by the teacher in } \\
\text { response to student needs. }\end{array}$ \\
\hline & $\begin{array}{l}\text { Reliability/ } \\
\text { Validity }\end{array}$ & $\begin{array}{l}\text { Standardized assessments, in conjunction with report card grades, allow parents to draw more informed } \\
\text { conclusions about their child's growth and achievement than either source alone can provide. }\end{array}$ \\
\hline
\end{tabular}

Note. AoL $=$ Assessment of learning; AfL = Assessment for learning; AaL = Assessment as learning. 
Table 8

Survey Blueprint for Part Two: Perceived Skill in Classroom Assessment

Please self-assess your skill level in relation to the following assessment practices using the scale provided. (scale: $1=$ novice, $2=$ =eginner, $3=$ proficient, $4=$ competent, $5=$ expert, NA=don't know)

\begin{tabular}{|c|c|c|}
\hline Part 2 Survey Items & $\begin{array}{c}\text { Classroom Assessment } \\
\text { Standard } \\
\text { (JCSEE, 2015) }\end{array}$ & $\begin{array}{c}\text { Assessment } \\
\text { Theme } \\
\text { (collapsed to 4) }\end{array}$ \\
\hline $\begin{array}{l}\text { 1. My practices have a clear purpose (e.g., diagnostic, formative, summative) that supports } \\
\text { teaching and learning toward curriculum expectations. }\end{array}$ & F1 Assessment purpose & $\begin{array}{l}\text { Assessment } \\
\text { Purposes }\end{array}$ \\
\hline 2. My assessment practices align with established curriculum expectations. & F2 Learning expectations & $\begin{array}{l}\text { Assessment } \\
\text { Purposes }\end{array}$ \\
\hline $\begin{array}{l}\text { 3. My methods and types of assessment allow students to demonstrate their learning in } \\
\text { diverse ways. }\end{array}$ & F3 Assessment design & $\begin{array}{l}\text { Assessment } \\
\text { Processes }\end{array}$ \\
\hline 4. I continuously engage students in assessment processes. & $\begin{array}{l}\text { F4 Student engagement in } \\
\text { assessment }\end{array}$ & $\begin{array}{l}\text { Assessment } \\
\text { Processes }\end{array}$ \\
\hline 5. I use assessment evidence to enhance students' learning. & $\begin{array}{l}\text { F4 Student engagement in } \\
\text { assessment }\end{array}$ & $\begin{array}{l}\text { Assessment } \\
\text { Processes }\end{array}$ \\
\hline $\begin{array}{l}\text { 6. I provide adequate student preparation for assessments in terms of resources, time, and } \\
\text { learning opportunities. }\end{array}$ & F5 Assessment preparation & $\begin{array}{l}\text { Assessment } \\
\text { Processes }\end{array}$ \\
\hline $\begin{array}{l}\text { 7. I use deliberate and continuous strategy to communicate purposes and uses of } \\
\text { assessment to students. }\end{array}$ & $\begin{array}{l}\text { F6 Informed students \& } \\
\text { parents/guardians }\end{array}$ & $\begin{array}{l}\text { Assessment } \\
\text { Processes }\end{array}$ \\
\hline 8. I communicate purposes and uses of assessment to parents/guardians when appropriate. & $\begin{array}{l}\text { F6 Informed students \& } \\
\text { parents/guardians }\end{array}$ & $\begin{array}{l}\text { Assessment } \\
\text { Processes }\end{array}$ \\
\hline $\begin{array}{l}\text { 9. My assessments are responses and respectful of the cultural and linguistic diversity of } \\
\text { students. }\end{array}$ & $\begin{array}{l}\text { Q1 Cultural \& linguistic } \\
\text { diversity }\end{array}$ & $\begin{array}{l}\text { Assessment } \\
\text { Fairness }\end{array}$ \\
\hline $\begin{array}{l}\text { 10. I differentiate my assessment practices to meet the specific educational needs of all } \\
\text { students. }\end{array}$ & $\begin{array}{l}\text { Q2 Exceptionality \& special } \\
\text { education }\end{array}$ & $\begin{array}{l}\text { Assessment } \\
\text { Fairness }\end{array}$ \\
\hline $\begin{array}{l}\text { 11. My assessment decisions are only influenced by factors related to the intended } \\
\text { purposes of the assessment or the curriculum expectation being measured. }\end{array}$ & Q3 Freedom from bias & $\begin{array}{l}\text { Assessment } \\
\text { Fairness }\end{array}$ \\
\hline $\begin{array}{l}\text { 12. I provide adequate and appropriate information so that students and parents understand } \\
\text { the meaning of the feedback and grades I give. }\end{array}$ & U5 Reporting & $\begin{array}{l}\text { Assessment } \\
\text { Processes }\end{array}$ \\
\hline $\begin{array}{l}\text { 13. For each student, I use multiple, well-designed assessments to measure learning so that } \\
\text { I am confident in the grades I assign. }\end{array}$ & F3 Assessment design & $\begin{array}{l}\text { Assessment } \\
\text { Processes }\end{array}$ \\
\hline
\end{tabular}


14. I monitor and revise my assessment practice to improve the quality of my instruction.

15. I monitor and revise my assessment practice to improve my students' learning.

16. I am able to use a variety of strategies to analyze test and assessment results at both student and class levels.

17. I ensure that my assessments are fair, reliable, and provide valid information on student learning.

18. I provide timely feedback to students to improve their learning.

19. I provide useful feedback to students to improve their learning.

20. I use student performance data to inform instructional planning and next steps for individual students and the class as a whole.

21. My grades and comments are grounded in evidence I have collected about student achievement of learning expectations.

22. My reports are based on a sufficient body of evidence and provide a summary of student learning toward meeting curriculum expectations.

23. Throughout units of instruction, I regularly integrate various forms of formative and diagnostic assessment.

24. I engage students in monitoring their own learning and using assessment information to develop their learning skills and personalized learning plans.

25 . I have thought deeply about my approach to assessment.

26. I am able to articulate my personal philosophy of assessment recognizing its alignment and misalignment with assessment policies and theory.
F3 Assessment design

F3 Assessment design

U1 Analysis of student performance

Q4 Validity \& Q5 Reliability

U2 Effective feedback

U2 Effective feedback

U3 Instructional follow-up

U4 Grades and summative comments

U1 Analysis of student performance

F1 Assessment purpose

F4 Student engagement in assessment

Q6 Reflection

Q6 Reflection
Assessment

Processes

Assessment

Processes

Assessment

Purposes

Measurement

Theory

Assessment

Processes

Assessment

Processes

Assessment

Purposes

Assessment

Processes

Assessment

Purposes

Assessment

Purposes

Assessment

Processes

All 4 themes

All 4 themes

Note. $\mathrm{F}=$ Foundations. $\mathrm{Q}=$ Quality. $\mathrm{U}=$ Use. 
Table 9

Survey Blueprint for Part Three (A): Assessment Professional Learning Priorities

Please prioritize your interest in learning about the following aspects of classroom assessment using the scale provided. (scale: $1=$ very low, $2=$ low, $3=$ moderate, $4=$ high, $5=$ very high)

\section{Part 3(A) Survey Items}

1. Choosing the appropriate purpose of assessment (e.g., diagnostic, formative, summative) based on instructional goals and assessment policies.

2. Constructing assessments in alignment with current assessment theory, principles, and practices

3. Administering assessments in alignment with current assessment theory, principles, and practices.

4. Scoring assessments in alignment with current assessment theory, principles, and practices.

5. Interpreting and using assessment information in alignment with current assessment theory, principles, and practices.

6. Understanding current reporting and grading policies and theories.

7. Communicating assessment purposes, processes, and results to students, parents/guardians, and other stakeholders.

8. Cultivating fair assessment conditions for all learners, with sensitivity to student diversity and exceptional learners.

9. Disclosing accurate information about assessments. Protecting the rights and privacy of students that are assessed.

10. Understanding psychometric (i.e., technical) properties of assessments (e.g., reliability and validity).

11. Analyzing and using assessment information to guide instructional decisions and support student learning.

12. Integrating formative assessment (including assessment for and as learning) during instruction to guide next steps in teaching and learning.

\section{CAS}

(JCSEE, 2015)

F1, F2

F3, F4, F5, U1

F3, F4, F5, U1

F3, F4, F5, U1

F3, F4, F5, U1

F6, U4, U5

F6, U4, U5

Q1, Q2

Q3

Q4, Q5

F1-F5, U1

F1, U2, U3

\section{Assessment Theme}

(collapsed to 4)

Assessment Purposes

Assessment Processes

Assessment Processes

Assessment Processes

Assessment Processes

Assessment Processes

Assessment Processes

Assessment Fairness

Assessment Fairness

Measurement Theory

Assessment Purpose

Assessment Purposes

Note. $\mathrm{F}=$ Foundations. $\mathrm{Q}=$ Quality. $\mathrm{U}=$ Use. 
Table 10

Survey Blueprint for Part Three (B): Assessment Professional Learning Preferences

Please indicate your preferred mode(s) of educational support for learning about assessment. (scale: $1=$ not preferred, $2=$ somewhat preferred, $3=$ moderately preferred, $4=$ preferred, $5=$ highly preferred)

\section{Part 3(B) Survey Items}

1. Face-to-face full-length assessment course with a cohort of other practising teachers

2. Face-to-face short assessment module with a cohort of other practising teachers

3. Online full-length assessment course working independently

4. Online full-length assessment course working with cohort of other practising teachers

5. A series of short online assessment modules offered as independent studies

6. A series of short online assessment modules working with cohort of practising teachers

7. Classroom-embedded collaborative learning/inquiry working with colleagues

8. Classroom-embedded collaborative learning/inquiry working an expert

9. Blended learning courses (online with face-to-face)

10. Webinars

11. One-on-one mentoring with peer teacher

12. One-on-one mentoring with a support teacher

13. Self-study using selected resources (e.g., literature, video)

14. Professional development workshops

15. Other (please describe) 
Table 11

Distributions of Response Options for Part One: Approaches to Classroom Assessment Themes by Gender, Age, and Teaching

\section{Context Categories}

\begin{tabular}{|c|c|c|c|c|c|c|c|c|c|c|c|}
\hline \multirow[b]{2}{*}{ Theme } & \multirow[b]{2}{*}{ Response Option } & \multicolumn{2}{|c|}{ Gender } & \multicolumn{5}{|c|}{ Age } & \multicolumn{3}{|c|}{ Teaching Context } \\
\hline & & $\begin{array}{l}\text { Female } \\
(n=336)\end{array}$ & $\begin{array}{c}\text { Male } \\
(n=64)\end{array}$ & $\begin{array}{c}20-25 \\
(n=143)\end{array}$ & $\begin{array}{c}26-35 \\
(n=146)\end{array}$ & $\begin{array}{l}36-45 \\
(n=59)\end{array}$ & $\begin{array}{l}46-55 \\
(n=45)\end{array}$ & $\begin{array}{c}\text { Over } \\
55 \\
(n=12)\end{array}$ & $\begin{array}{l}\text { Public } \\
(n=204)\end{array}$ & $\begin{array}{l}\text { Catholic } \\
(n=43)\end{array}$ & $\begin{array}{l}\text { Independent } \\
\qquad(\mathrm{n}=59)\end{array}$ \\
\hline \multirow{3}{*}{$\begin{array}{c}\text { Assessment } \\
\text { Purposes }\end{array}$} & Assessment of Learning & 8.5 & 7.8 & 10.0 & 9.1 & 3.5 & 9.1 & 0.0 & 11.4 & 5.1 & 5.2 \\
\hline & Assessment for Learning & 66.9 & 62.5 & 61.4 & 67.8 & 75.4 & 63.6 & 66.7 & 63.2 & 66.7 & 72.4 \\
\hline & Assessment as Learning & 24.6 & 29.7 & 28.6 & 23.1 & 21.1 & 27.3 & 33.3 & 25.4 & 28.2 & 22.4 \\
\hline \multirow{3}{*}{$\begin{array}{c}\text { Assessment } \\
\text { Processes }\end{array}$} & Design & 46.2 & 48.4 & 43.3 & 51.4 & 39.7 & 51.2 & 33.0 & 48.2 & 35.0 & 45.8 \\
\hline & Use/Scoring & 5.1 & 3.1 & 8.5 & 3.5 & 1.7 & 2.3 & 0.0 & 5.2 & 2.5 & 1.7 \\
\hline & Communication & 48.6 & 48.4 & 48.2 & 45.1 & 58.6 & 46.5 & 66.7 & 46.6 & 62.5 & 52.5 \\
\hline \multirow{3}{*}{ Fairness } & Standard treatment & 10.8 & 13.1 & 12.1 & 10.8 & 13.6 & 7.5 & 0.00 & 9.5 & 15.4 & 19.0 \\
\hline & Equitable treatment & 32.3 & 31.1 & 34.3 & 32.4 & 23.7 & 40.0 & 9.1 & 36.5 & 25.6 & 24.1 \\
\hline & Differentiated approach & 56.9 & 55.7 & 53.6 & 56.8 & 62.7 & 52.5 & 90.9 & 54.0 & 59.0 & 56.9 \\
\hline \multirow{3}{*}{$\begin{array}{l}\text { Measurement } \\
\text { Theory }\end{array}$} & Reliability & 19.1 & 22.6 & 19.9 & 22.4 & 17.5 & 22.0 & 0.0 & 16.7 & 23.7 & 25.9 \\
\hline & Validity & 27.0 & 24.2 & 23.4 & 27.3 & 35.1 & 26.8 & 8.3 & 31.8 & 18.4 & 17.2 \\
\hline & Reliability \& Validity & 53.9 & 53.2 & 56.7 & 50.3 & 47.4 & 51.2 & 91.7 & 51.6 & 57.9 & 56.9 \\
\hline
\end{tabular}

Note. The percentages within each set of rows (Theme) for each column (Category) add up to 100\%. 
Table 12

Results of Principal Component Analysis of Part Two: Perceived Skill in Classroom Assessment

\begin{tabular}{|c|c|c|}
\hline & $\begin{array}{l}\text { Monitoring, } \\
\text { Analyzing, and } \\
\text { Communicating } \\
\text { Assessment Results }\end{array}$ & $\begin{array}{l}\text { Assessment } \\
\text { Design, } \\
\text { Implementation } \\
\text { and Feedback }\end{array}$ \\
\hline $\begin{array}{l}\text { 1. My practices have a clear purpose (e.g., diagnostic, } \\
\text { formative, summative) that supports teaching and } \\
\text { learning towards achievement of curriculum } \\
\text { expectations. }\end{array}$ & & .702 \\
\hline $\begin{array}{l}\text { 2. My assessment practices align with the established } \\
\text { curriculum expectations }\end{array}$ & & .755 \\
\hline $\begin{array}{l}\text { 6. I provide adequate student preparation for assessments } \\
\text { in terms of resources, time, and learning opportunities. }\end{array}$ & & .715 \\
\hline $\begin{array}{l}\text { 8. I communicate purposes and uses of assessment to } \\
\text { parents/guardians when appropriate. }\end{array}$ & .793 & \\
\hline $\begin{array}{l}\text { 14. I monitor and revise my assessment practice to } \\
\text { improve the quality of my instructional practice. }\end{array}$ & .659 & \\
\hline $\begin{array}{l}\text { 16. I am able to use a variety of strategies to analyze test } \\
\text { and assessment results at both student and class levels. }\end{array}$ & .817 & \\
\hline $\begin{array}{l}\text { 18. I provide timely feedback to students to improve their } \\
\text { learning. }\end{array}$ & & .932 \\
\hline $\begin{array}{l}\text { 19. I provide useful feedback to students to improve their } \\
\text { learning. }\end{array}$ & & .876 \\
\hline $\begin{array}{l}\text { 22. My reports are based on a sufficient body of evidence } \\
\text { and provide a summary of student learning toward } \\
\text { meeting curriculum expectations. }\end{array}$ & .780 & \\
\hline $\begin{array}{l}\text { 24. I engage students in monitoring their own learning } \\
\text { and using assessment information to develop their } \\
\text { learning skills and personalized learning plans. }\end{array}$ & .742 & \\
\hline $\begin{array}{l}25 . \text { I have thought deeply about my approach to } \\
\text { assessment. }\end{array}$ & .845 & \\
\hline $\begin{array}{l}\text { 26. I am able to articulate my personal philosophy of } \\
\text { assessment recognizing its alignment and misalignment } \\
\text { with assessment policies and theory. }\end{array}$ & .792 & \\
\hline$\%$ of variance explained & $58.7 \%$ & $8.17 \%$ \\
\hline
\end{tabular}




\section{Table 13}

Descriptive Statistics for Part Two: Perceived Skill in Classroom Assessment

\begin{tabular}{|c|c|c|}
\hline Subscales and Items & $\mathbf{M}$ & SD \\
\hline Subscale: Monitoring, Analyzing, and Communicating Assessment Results & 3.70 & 0.77 \\
\hline $\begin{array}{l}\text { 1. My practices have a clear purpose (e.g., diagnostic, formative, summative) that supports } \\
\text { teaching and learning towards achievement of curriculum expectations. }\end{array}$ & 3.51 & 0.90 \\
\hline 2. My assessment practices align with the established curriculum expectations & 3.75 & 0.92 \\
\hline $\begin{array}{l}\text { 6. I provide adequate student preparation for assessments in terms of resources, time, and } \\
\text { learning opportunities. }\end{array}$ & 3.70 & 0.96 \\
\hline 18. I provide timely feedback to students to improve their learning. & 3.76 & 0.96 \\
\hline 19. I provide useful feedback to students to improve their learning. & 3.80 & 0.93 \\
\hline Subscale: Assessment Design, Implementation, and Feedback & 3.31 & 0.95 \\
\hline 8. I communicate purposes and uses of assessment to parents/guardians when appropriate. & 3.03 & 1.40 \\
\hline $\begin{array}{l}\text { 14. I monitor and revise my assessment practice to improve the quality of my instructional } \\
\text { practice. }\end{array}$ & 3.64 & 1.06 \\
\hline $\begin{array}{l}\text { 16. I am able to use a variety of strategies to analyze test and assessment results at both } \\
\text { student and class levels. }\end{array}$ & 3.32 & 1.15 \\
\hline $\begin{array}{l}\text { 22. My reports are based on a sufficient body of evidence and provide a summary of } \\
\text { student learning toward meeting curriculum expectations. }\end{array}$ & 3.34 & 1.32 \\
\hline $\begin{array}{l}\text { 24. I engage students in monitoring their own learning and using assessment information } \\
\text { to develop their learning skills and personalized learning plans. }\end{array}$ & 3.13 & 1.12 \\
\hline 25. I have thought deeply about my approach to assessment. & 3.43 & 1.06 \\
\hline $\begin{array}{l}\text { 26. I am able to articulate my personal philosophy of assessment recognizing its alignment } \\
\text { and misalignment with assessment policies and theory. }\end{array}$ & 3.24 & 1.16 \\
\hline
\end{tabular}


Table 14

Results of Principal Component Analysis of Part Three (A): Professional Learning Priorities

\begin{tabular}{|c|c|c|}
\hline & $\begin{array}{l}\text { Integrating and } \\
\text { Communicating } \\
\text { Assessment } \\
\text { Practices }\end{array}$ & $\begin{array}{l}\text { Alignment with } \\
\text { Current Assessment } \\
\text { Theory, Principles, } \\
\text { and Practices }\end{array}$ \\
\hline $\begin{array}{l}\text { 1. Choosing the appropriate purpose of assessment (e.g., } \\
\text { diagnostic, formative, summative) based on instructional } \\
\text { goals and assessment }\end{array}$ & 0.678 & \\
\hline $\begin{array}{l}\text { 2. Constructing assessments in alignment with current } \\
\text { assessment theory, principles, and practices. }\end{array}$ & & 0.889 \\
\hline $\begin{array}{l}\text { 3. Administering assessments in alignment with current } \\
\text { assessment theory, principles, and practices. }\end{array}$ & & 0.875 \\
\hline $\begin{array}{l}\text { 4. Scoring assessments in alignment with current } \\
\text { assessment theory, principles, and practices. }\end{array}$ & & 0.892 \\
\hline $\begin{array}{l}\text { 5. Interpreting and using assessment information in } \\
\text { alignment with current assessment theory, principles, and } \\
\text { practices. }\end{array}$ & & 0.823 \\
\hline $\begin{array}{l}\text { 7. Communicating assessment purposes, processes, and } \\
\text { results to students, parents/guardians, and other } \\
\text { stakeholders. }\end{array}$ & 0.796 & \\
\hline $\begin{array}{l}\text { 8. Cultivating fair assessment conditions for all learners, } \\
\text { with sensitivity to student diversity and exceptional } \\
\text { learners. }\end{array}$ & 0.822 & \\
\hline $\begin{array}{l}\text { 9. Disclosing accurate information about assessments. } \\
\text { Protecting the rights and privacy of students that are } \\
\text { assessed. }\end{array}$ & 0.697 & \\
\hline $\begin{array}{l}\text { 11. Integrating formative assessment (including } \\
\text { assessment for and as learning) during instruction to } \\
\text { guide next steps in teaching a }\end{array}$ & 0.710 & \\
\hline $\begin{array}{l}\text { 12. Analyzing and using assessment information to guide } \\
\text { instructional decisions and support student learning. }\end{array}$ & 0.703 & \\
\hline$\%$ of variance explained & $48.1 \%$ & $15.5 \%$ \\
\hline
\end{tabular}


Table 15

Descriptive Statistics for Part Three (A): Professional Learning Priorities

\begin{tabular}{lcc}
\hline Subscales and Items & M & SD \\
\hline Subscale: Integrating and Communicating Assessment Practices & $\mathbf{3 . 7 4}$ & $\mathbf{0 . 6 7}$ \\
\hline $\begin{array}{l}\text { 1. Choosing the appropriate purpose of assessment (e.g., diagnostic, } \\
\text { formative, summative) based on instructional goals and assessments }\end{array}$ & 3.41 & 0.96 \\
$\begin{array}{l}\text { 7. Communicating assessment purposes, processes, and results to } \\
\text { students, parents/guardians, and other stakeholders. }\end{array}$ & 3.66 & 0.91 \\
$\begin{array}{l}\text { 8. Cultivating fair assessment conditions for all learners, with sensitivity } \\
\text { to student diversity and exceptional learners. }\end{array}$ & 4.06 & 0.81 \\
$\begin{array}{l}\text { 9. Disclosing accurate information about assessments. Protecting the } \\
\text { rights and privacy of students that are assessed. }\end{array}$ & 3.47 & 1.06 \\
$\begin{array}{l}\text { 11. Integrating formative assessment (including assessment for and as } \\
\text { learning) during instruction to guide next steps in teaching a }\end{array}$ & 3.88 & 0.85 \\
$\begin{array}{l}\text { 12. Analyzing and using assessment information to guide instructional } \\
\text { decisions and support student learning. }\end{array}$ & 3.90 & 0.84 \\
\hline $\begin{array}{l}\text { Subscale: } \text { Alignment with Current } \text { Assessment } \text { Theory, Principles, } \\
\text { and Practices }\end{array}$ & $\mathbf{3 . 4 2}$ & $\mathbf{0 . 7 7}$ \\
\hline $\begin{array}{l}\text { 2. Constructing assessments in alignment with current assessment } \\
\text { theory, principles, and practices. }\end{array}$ & 3.43 & 0.87 \\
$\begin{array}{l}\text { 3. Administering assessments in alignment with current assessment } \\
\text { theory, principles, and practices. }\end{array}$ & 3.36 & 0.87 \\
$\begin{array}{l}\text { 4. Scoring assessments in alignment with current assessment theory, } \\
\text { principles, and practices. }\end{array}$ & 3.37 & 0.90 \\
$\begin{array}{l}\text { 5. Interpreting and using assessment information in alignment with } \\
\text { current assessment theory, principles, and practices. }\end{array}$ & 3.52 & 0.89 \\
\hline
\end{tabular}


Table 16

Results of Principal Component Analysis of Part Three (B): Professional Learning Preferences

\begin{tabular}{|c|c|c|c|}
\hline & $\begin{array}{l}\text { Online } \\
\text { Learning }\end{array}$ & $\begin{array}{l}\text { Face-to-Face, } \\
\text { Group Learning }\end{array}$ & $\begin{array}{l}\text { One-on-One } \\
\text { Learning }\end{array}$ \\
\hline $\begin{array}{l}\text { 1. Face-to-face full-length assessment course with a } \\
\text { cohort of other practising teachers }\end{array}$ & & 0.621 & \\
\hline $\begin{array}{l}\text { 2. Face-to-face short assessment module with a cohort } \\
\text { of other practising teachers }\end{array}$ & & 0.723 & \\
\hline $\begin{array}{l}\text { 3. Online full-length assessment course working } \\
\text { independently }\end{array}$ & 0.811 & & \\
\hline $\begin{array}{l}\text { 4. Online full-length assessment course working with } \\
\text { cohort of other practising teachers }\end{array}$ & 0.826 & & \\
\hline $\begin{array}{l}\text { 5. A series of short online assessment modules offered } \\
\text { as independent studies }\end{array}$ & 0.847 & & \\
\hline $\begin{array}{l}\text { 6. A series of short online assessment modules working } \\
\text { with cohort of practising teachers }\end{array}$ & 0.829 & & \\
\hline $\begin{array}{l}\text { 7. Classroom-embedded collaborative learning/inquiry } \\
\text { working with colleagues }\end{array}$ & & 0.806 & \\
\hline $\begin{array}{l}\text { 8. Classroom-embedded collaborative learning/inquiry } \\
\text { working an expert. }\end{array}$ & & 0.835 & \\
\hline 10. Webinars & 0.640 & & \\
\hline 11. One-on-one mentoring with peer teacher. & & & 0.973 \\
\hline 12. One-on-one mentoring with a support teacher. & & & 0.952 \\
\hline$\%$ of variance explained & $29.6 \%$ & $26.6 \%$ & $10.6 \%$ \\
\hline
\end{tabular}


Table 17

Descriptive Statistics for Part Three (B): Professional Learning Preferences

\begin{tabular}{lcc}
\hline Subscales and Items & M & SD \\
\hline Subscale: Online Learning & $\mathbf{2 . 5 8}$ & $\mathbf{0 . 9 7}$ \\
\hline 3. Online full-length assessment course working independently & 2.47 & 1.22 \\
4. Online full-length assessment course working with cohort of other & 2.57 & 1.24 \\
practising teachers & & \\
5. A series of short online assessment modules offered as independent studies & 2.80 & 1.25 \\
6. A series of short online assessment modules working with cohort of & 2.80 & 1.24 \\
practising teachers & 2.26 & 1.12 \\
10. Webinars & $\mathbf{2 . 5 8}$ & $\mathbf{0 . 9 7}$ \\
\hline Subscale: Face-to-Face, Group Learning & 2.92 & 1.22 \\
\hline $\begin{array}{l}\text { 1. Face-to-face full-length assessment course with a cohort of other } \\
\text { practising teachers }\end{array}$ & 3.28 & 1.11 \\
\hline 2. Face-to-face short assessment module with a cohort of other practising & & \\
teachers & 3.73 & 1.04 \\
\hline 7. Classroom-embedded collaborative learning/inquiry working with & & \\
colleagues & 3.75 & 1.06 \\
\hline 8. Classroom-embedded collaborative learning/inquiry working an expert & $\mathbf{3 . 4 0}$ & $\mathbf{1 . 1 5}$ \\
\hline Subscale: One-on-One Learning & 3.39 & 1.20 \\
\hline 11. One-on-one mentoring with peer teacher & 3.41 & 1.17 \\
\hline 12. One-on-one mentoring with a support teacher &
\end{tabular}


Table 18

Correlations between Part Three (B) Subscales

\begin{tabular}{l|ccc}
\hline & $\begin{array}{c}\text { Online } \\
\text { Learning }\end{array}$ & $\begin{array}{c}\text { Face-to-Face, Group } \\
\text { Learning }\end{array}$ & $\begin{array}{c}\text { One-on-One } \\
\text { Learning }\end{array}$ \\
\hline Online Learning & 1.00 & -0.10 & 0.04 \\
Face-to-Face, Group & -0.10 & 1.00 & 0.42 \\
Learning & 0.04 & 0.42 & 1.00 \\
One-on-One Learning & & & \\
\hline
\end{tabular}

